\title{
A comparative study of the retirement confidence level between domestic workers and OFW as linked to their job commitment
}

\author{
Marycris O. Albao * \\ De La Salle University, Manila, Philippines
}

\author{
Keywords \\ Goal clarity \\ Retirement confidence \\ Commitment
}

Received: 8 May 2018

Accepted: 17 May 2018

Published: 6 June 2018

\begin{abstract}
The paper investigated the retirement confidence among Domestic and Overseas Filipino Workers concerning job commitment. Specifically, the study determined the relationship between clarity of retirement goal and retirement confidence that refers to the quality of life that could still be maintained during retirement. For several studies, savings already provided perceived confidence for retirement to retirees, but this study would check if the perception still applies. Today, banks in the Philippines offer a savings interest rate of less than $1 \%$ (excluding withholding tax) with the current inflation rate target of $4.3 \%$. Purposive sampling was employed to determine the respondents who were domestic and overseas Filipino workers in the United Arab Emirates and New York. An explanatory-causal design was utilized to explain the relationship/influence and effect of the variable/s on the retirement confidence. The results of the regression indicated that the predictor for retirement confidence explained $55.4 \%$ of the variance $\left(\mathrm{R}^{2}=.55, F(4,13)=4.03, p<0.05\right)$. It was found that job investment $(p<.01)$ significantly predicted retirement confidence. The result of the correlation of retirement confidence to the job commitment proves significant, $(r(18)=0.50, p<.05)$. The study output could motivate government agencies to review mandatory retirement packages that direct employers offer their employees for a comfortable retirement.
\end{abstract}

(C) 2018 The Author(s). Published by TAF Publishing.

\section{INTRODUCTION}

Retirement confidence is influenced by demographic-socio economic, and attitude in choosing standard of living. The increasing cost of bills significantly affects the retirement confidence (Goda, Manchester, \& Sojourner, 2013). When these factors influence how domestic or overseas Filipino workers view their employment as a central life interest, rather than just a place to earn money, job commitment will be higher (Ardyanfitri, 2016; Herold, Fedor, Caldwell, \& Liu, 2008; Selvina, 2016). Considering work as a central aspect of life enables workers to feel happier and be more punctual. Active participation in the job is also an essential part of job commitment.

The retirement status will serve as a reward on how much one invested prior to the retirement. According to Newman, Jeon, and Hulin (2013) the retirement attitude is the differ- ence between the extent of effort you save for retirement and what you will receive during retirement. It was made known as a study result of (Lauren \& Brandi, n.d) that giving early education on the importance of retirement planning during younger years in employment may provide more retirement preparedness to employees. Caryl (2011) and Yaemjamuang (2017), stressed that investment model had proven a degree of commitment engagement goal.

For the period 2006-2015, the Philippines, compared to other ASEAN countries, ranked first in gross savings (\% of GDP), and an average savings of 50.10\% (Green, Finkel, Fitzsimons, \& Gino, 2017; Hashim, Pin, \& Isa, 2017; Piyachat, 2017). People's ability to increase savings was influenced by good economic importance of retirement planning, but there was failure in implementing the plan as influenced by the attitude or low income to enable to save.

* corresponding author: Marycris 0 . Albao

†email: marycris.Albao@dlsu.edu.ph 
The Consumer Expectations Survey done by the Philippine Central Bank or BSP revealed that $54.9 \%$ of Filipino Households were not able to save by at least $10 \%$ of their income during the first quarter of 2017 (Optimistic, 2017). There was a decline basing on their record from the previous survey, including those household with OFWs; only $1.9 \%$ of these OFWs were able to save.

The Self Rated Poverty in September 2015 revealed that households with OFW member have lower poverty rate than households with no OFW member. Funds from saving are reserved for emergencies, education, retirement, health and hospitalization, and acquisition of real estate which includes capital for business (Chipongian, 2017; Hoai \& Thanwadee, 2015).

For 2018, the Philippine economy is projected to expand and thus there will be a raise in investments and productivity that will provide employment opportunities to Filipinos (https://goo.gl/JCAe8Q). Yet, favorable investment opportunities do not ensure employment benefits that will allow retirement confidence and encouragement for job commitment among Filipino workers. Records from the Philippine Statistics Authority disclosed that employment rate increases by $5.3 \%$ as of January, 2018 (https://goo.gl/AoV6KJ). Studies conducted established a perceived confidence for retirement to the would-be retirees, but the perception is uncertainly applied, especially on savings. Banks today offer a savings interest rate of less than $1 \%$ (excluding withholding tax) and considering the Philippine inflation rate target which is at $4.3 \%$ (De vera \& Lucas, 2018; Madiawati \& Pradana, 2016). The Commission on Filipinos Overseas estimates that there are $10 \%$ or around 9 million Filipinos get employment overseas to support their families and also enjoy more incentives like a free round trip ticket, one month vacation with pay, bonus and the like (United Arab Emirates, 2017). Most importantly, they can have enough funds to pay for government initiated retirement security provision to ensure confidence during retirement.

Retirement is inevitable. The extent of the benefits from the job will provide an opportunity for an employee to prepare for his retirement in the future, a justification of an employee to become committed to his job. Many articles and studies revealed that being an OFW is not that easy, contrary to the general views of many that OFWs have lots of money and live a luxurious life abroad. OFWs need to be careful about how their earnings will be allocated.

\section{Objectives of the Study}

The study examined the retirement confidence among domestic and overseas Filipino workers' in relation to job commitment. The following were the specific objectives:

1. to determine the relationship of the retirement confidence of domestic and overseas Filipino workers as to:

a. demographic factors and

b. goal clarity of retirement;

2. to identify the level of retirement confidence of domestic and overseas Filipino workers;

3. to evaluate the influence of the following on retirement confidence and job commitment:

a. Job Rewards,

b. Job Costs,

c. Job Alternatives, and

d. Job Investments; and,

4. to determine the relationship between job commitment and retirement confidence among domestic and overseas Filipino workers.

\section{RELATED LITERATURE}

Retirement is an expected stage in the life of human resource. But how could any worker prepare himself to face the retirement stage? With Retirement Confidence, the worker could prepare to face the challenges of retirement without fear by being able to save funds.

The study about the Retirement Preparedness of Middle Income Filipinos revealed the lack of full readiness to face retirement in terms of financial and contingency planning (Mandigma, 2016). The past research involvingthe parents of commerce students in the comprehensive university in the Philippines focused its discussion on the four dimensions to determine retirement readiness namely: happiness, health, wealth and contingency planning. The present study, however, made use of the domestic and overseas Filipino workers to discuss the confidence level that was linked to demographic factors and goals of clarity of retirement. Both studies were related to retirement but the previous was more on readiness while the current is on confidence level. The four dimensions on retirement readiness could be used to establish the areas in which Filipino workers from domestic or overseas need to improve their retirement confidence. The study of Sabri and Juen (2014) among Malaysian Public sector showed that the confidence to retire by the covered respondents correlates positively with financial literacy, saving behavior, and financial management. Unlike the present study which involved the retirement confidence of both sexes, the previous study focused its discussion mainly on Malaysian working women, leav- 
ing the picture of the men's confidence level for retirement behind. Involving the men could inspire policy planners of retirement programs to prepare gender-based retirement scheme that caters both sexes equally.

\section{Demographic Factors}

The study of Mansor, Hong, Abu, and Shaari (2015) stressed that the extent of planning may depend on the personality and resources available to the would be retiree after conducting an investigation on the relationship between demographic factors as independent and retirement planning as dependent variable. The results revealed high relationship retirement planning between demographic variables like age, level of education and household income. Gender, on the other hand, reflected less relationship with retirement confidence. Asset ownership needs to be examined further to establish better relationship with retirement planning. The study of Britiller, Pesigan, Pillado, Portuguese, and Principe (2013) on the Life Satisfaction of Adults in Retirement Age evaluated the relationship between the respondents' profile and the satisfaction level of adults as would be retirees. The following dimensions for life satisfaction upon retirement were used to assess life satisfaction (or the independent variables) such as gender, civil status, religion and economic status. Among the respondents' profile, gender and religion of adults in retirement age were not significant predictors. Further study could be conducted to determine the significant relationship between other independent variables such as number of dependent children, number of children who are employed, $\%$ of family expenditures and retirement income.

\section{Goal Clarity of Retirement}

Goal Clarity of Retirement Goals suggests clarity of purpose or aim in planning better for retirement. Such planning could make the retiree adjust life to retirement stage and its challenges. Global Saving and Investment Report (2014) stressed that among the respondents, majority had confidence in reaching their future financial target, as supported by their good financial planning. Further studies could help those with lesser confidence to find ways to diversify their investment acquisitions. Study to predict paths for wiser income allocation could be conducted to highlight strategies that make this possible to attain.

\section{Job Commitment}

Commitment refers to the availability to engage in a certain task, activity and to the organization. This involves the passion, sense of responsibility, and concern. The study of Lee (2016) revealed that only $34 \%$ of the respondents did not perceive that they are engaged with their work and the organization. Thus, it connotes that they are not committed. Results revealed that only $33 \%$ of the respondents do not have a clear understanding of the organization's vision and mission. Also, majority of the respondents as workers valued compensation and benefit in terms of job satisfaction which will motivate them to stay to continually engage in the organization and their work. The previous study did not specify how clear understanding of organization's vision and mission could make workers engaged. Qualifying the respondents' responses based on actual work setting could be undertaken as a follow up research.

The study of Semmer, Elfering, Baillod, Berset, and Beehr (2014)revealed that employees leave their job because of "push" motivation, and others leave because they were attracted to another job (pull motivation). There are organizations that lead in motivating people to show their best capability to do the work. These are done through giving financial and non- financial advantage to the employees. Today, employers take initiative in providing various trainings to nourish employees with knowledge and skills to transform them into great workers. This is an initiative of making employees align with their work and eventually help the organization too in the achievement of its goal. The perception of having a comfortable retirement and stay committed to the job as well may be associated with the following factors such as job investments, job rewards, job alternatives and job costs Employers in the overseas specifically in United Arab Emirates are improving their employment package offering to lessen employees' turnover (United Arab Emirates, 2017). Also the study of Treuren (2013) revealed that the employees' intention to leave is positively correlated with their perceived job alternatives. From the survey conducted among finance executives, $43 \%$ believe that their employees will retire on time to not having fund at the time of retirement (Prudential Financial, 2017). Further study is needed for the sample size is that very small and the result may be due to social desirability bias.

\section{Job Investments}

Job investments are evidenced by time and efforts exerted by workers who are engaged in trainings provided by their employers. Some training could be industry related and some are not. Such investments utilize human capital resources to acquire improvement in knowledge and skills from internal or external trainings. 


\section{Job Rewards}

Job rewards are benefits that are due for the employee in exchange of the expectations by the employer related to productivity and efficiency or company goal achievement. These could be given in the form of financial or nonfinancial nature. Employee will be pulled to devote his time longer to his job because of his personal interest or the utilitarian function of the reward. Employers in the overseas specifically in United Arab Emirates are improving their employment package offering to lessen employees' turnover (United Arab Emirates, 2017).

\section{Job Alternatives}

Job alternatives refer to the available job opportunities that will allow the employee to gain advantage in moving from the current job. The study of Treuren (2013) revealed that the employees' intention to leave is positively correlated with their perceived job alternatives. Further study is needed for the sample size that is very small and the result may be due to social desirability bias.

\section{Job Costs}

Retiring on time may provide benefit for the employee to enjoy more in life while not working and still being able to do activities that will require physical strength. But there are employees who will wish to extend more years before retiring due to limited financial resources they have. Some employees perceive that their funds are not enough to sustain for comfortable retirement requirement.

\section{Research Hypothesis}

The following were the hypotheses tested in the study:

H1-1: Job reward, job costs, job alternatives, and job investments do not influence the retirement confidence of Filipino workers domestically and overseas.

H2-1: Job reward, job costs, job alternatives, and job investments influence the retirement confidence of Filipino workers domestically and overseas..

H1-2: Job commitment does not have relationship on the retirement confidence among the domestic and overseas Filipino workers

H2-2: Job commitment has a relationship with retirement confidence of the domestic and overseas Filipino workers.

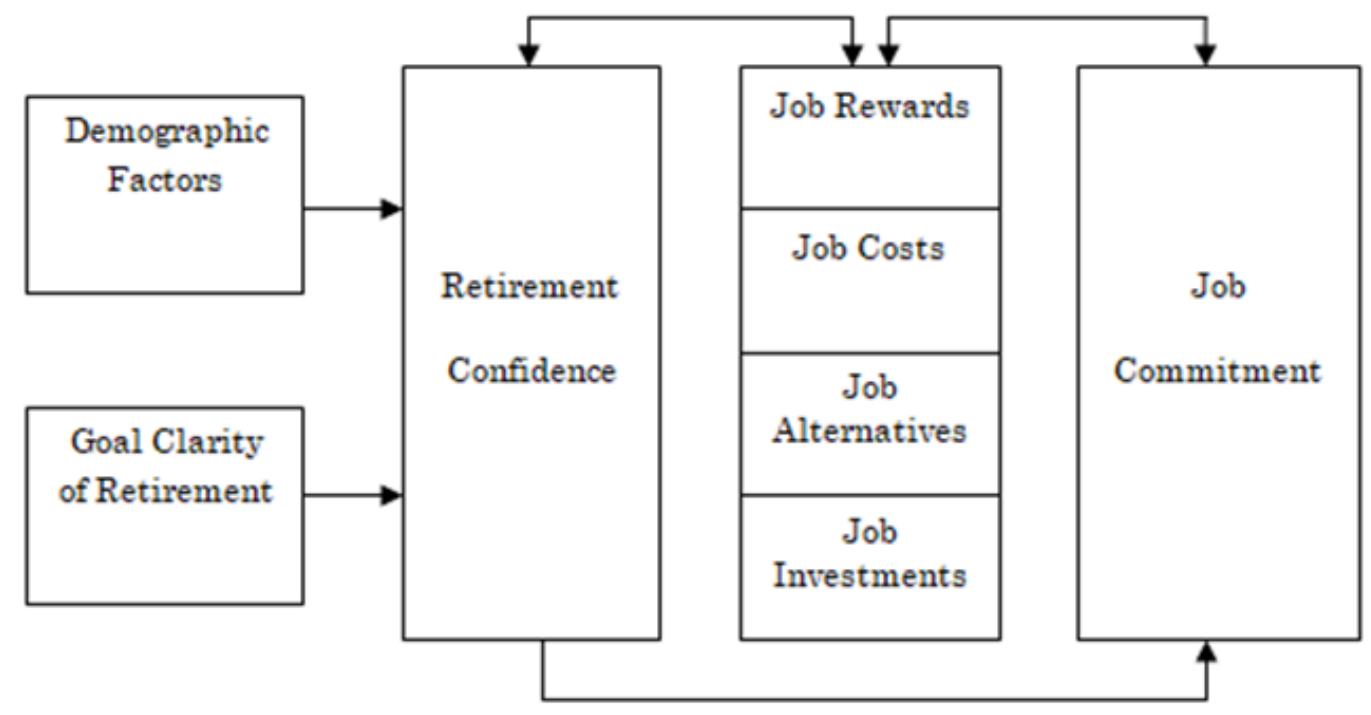

FIGURE 1. Testing hypothesis

\section{METHODOLOGY}

This research utilized explanatory causal design to explain relationship/influence and effect of the variable/s on the retirement confidence and job commitment. The study was conducted in the area of work by the respondents. There were some facilitators in the distribution and retrieving of questionnaires.Convenience Sampling was utilized to gather data from domestic and overseas Filipino workers from Dubai, Qatar, and Saudi Arabia and New York. Respon- dents covered in the study were all working in the academe and various industries who are at least 21 years of age. A total of 36 out of 50 questionnaires was retrieved. The survey questionnaire consisted of 4 parts.

\section{Survey Instrument}

The cover page was a consent form. Second page consists of the General instruction and Part 1 no. 1 which contained 3 questions about job rewards answerable by a five point 
scale. Part 1 no. 2 contained 3 questions related to job costs. Part 1 no. c contained 3 questions asking on the degree of availability of job alternatives, Part $1 \mathrm{~d}$ contained 3 questions related to extent of job investments and Part 1 e 3 questions were related to job commitment. Part 2 was composed of 5 questions about the clarity of retirement goals answerable by yes or no. Part 3 contained questions related to retirement confidence and open-ended questions for further justification of their choices. Part 4 was about the respondent's background.Questionnaire was patterned from the study of (Caryl, 2011). Questions for goal clarity of retirement were patterned from the study of Shanmugam, Abidin, and Tolos (2017).

\section{Statistical Treatment of Data}

For the data analysis, the study gives importance to the software R studio in testing and analyzing the following:

a. use of one way ANOVA, in order to determine the dispersion of the sample size.

b. correlation test, in order to determine the relationship of variables involved.

c. regression analysis for the determination of the significant effect of the variables involve in the study.

The study also employed descriptive analysis using frequency, percentages and mean to analyze the demographic factors and other variables involved.

\section{DISCUSSION AND RESULTS}

The results on Table 1 revealed that the sample respondents in the study vary with each other.

TABLE 1. One way ANOVA for independent variable age

\begin{tabular}{llllllll}
\hline \hline Age & Count & $\boldsymbol{d} \boldsymbol{f}$ & Sum of Squares & Mean Square & F Value & P Value & S.D \\
\hline Group & & 4 & 463.9 & 115.97 & 1.643 & 0.189 & \\
Domestic & 18 & & & 37.27778 & & & 10.68702 \\
Dubai & 8 & & & 32.75 & & & 4.832923 \\
New York & 6 & & & 42.33333 & & & 3.614784 \\
Qatar & 1 & & & 48 & & NA \\
Saudi & 3 & & & 34 & & 3 \\
Residuals & & 31 & 2188.4 & 70.59 & & \\
\hline \hline
\end{tabular}

TABLE 2. Descriptive statistics mean of independent variables and dependent variable

\begin{tabular}{lc}
\hline \hline Variables & Mean \\
\hline Group mean retirement confidence & \\
Domestic Filipino workers & 1.91 \\
Overseas Filipino workers & 2.14 \\
Group mean goal clarity for retirement & \\
Domestic Filipino workers & 0.62 \\
Overseas Filipino workers & 0.6 \\
Group mean job commitment & \\
Domestic Filipino workers & 3.62 \\
Overseas Filipino workers & 3.89 \\
\hline \hline
\end{tabular}

\section{Results of Hypothesis Tests}

The results state that only job investment has influence on the retirement confidence to the Filipino workers in the domestic, $\left(R^{2}=.55, F(4,13)=4.03, p<0.05\right.$ while job alternatives has influence on the overseas, $\left(R^{2}=.99, F(4,13)\right.$ $=1535, p<.001)$. Further, the results also revealed that among overseas Filipino workers retirement confidence is positively correlated with job commitment.

\section{Correlation between Demographic Factors and Retire- ment Confidence}

Table 3, above shows that gender, marital status, home ownership and goal clarity for retirement were significantly correlated with the retirement confidence among domestic Filipino workers. The result revealed that gender and retirement confidence were positively related, $(r(18)=-0.55$, $p<.05)$.

Also, the results showed positive relation between marital 
status and retirement confidence, $(r(18)=-0.543, p<.05)$, between home ownership and retirement confidence, $(r$ $(18)=0.56, p<.05)$, and between clarity of goal for retirement and retirement confidence, $(r(18)=.54, p<.05)$. While among the overseas Filipino workers only age has a significant association with retirement confidence, $(r$ (18) $=$ $-0.562, p<.05)$. These results are supported by the study of Britiller et al. (2013).

TABLE 3. Spearman rho correlation of independent variables and dependent variable

\begin{tabular}{lllllll}
\hline \hline Retirement Confidence & \multicolumn{7}{l}{} \\
& \multicolumn{7}{l}{ Domestic } & \multicolumn{3}{l}{ Overseas } \\
\cline { 2 - 7 } & Rho & $\boldsymbol{p}$-value & Conclusion & Rho & $\boldsymbol{p}$-value & Conclusion \\
\hline Age & -0.284 & & 0.2525 Not Significant & -0.513 & 0.029 & Significant \\
Gender & -0.551 & 0.0178 & Significant & -0.2283 & 0.3622 & Not Significant \\
Marstat & -0.543 & 0.0197 & Significant & -0.1595 & 0.5273 & Not Significant \\
Own home & 0.5186 & 0.0274 & Significant & 0.559 & 0.0159 & Significant \\
Goal Clarity & 0.537 & 0.0214 & Significant & 0.4124 & 0.089 & Not Significant \\
\hline \hline
\end{tabular}

Note. $\dagger=p<.10,{ }^{*}=p<.05,{ }^{* *}=p<.01,^{*}=p<.001 . N=18$ for domestic workersand 18 for Overseas' workers for all analyses

\section{Level of Retirement Confidence of Domestic and Over- seas Filipino Workers}

Domestic Filipino workers were not too confident as shown by the mean score of 1.91 while the overseas Filipino workers were somewhat confident based on the mean of 2.14. From the study a mean score of 3 means very confident, 2 means somewhat confident, 1 not too confident and 0 not at all confident. The age group between domestic and overseas Filipino workers in this study differs, thus there is a retirement confidence variance. This is supported by the study of Shanmugam et al. (2017) who mentioned that retirement confidence of Malaysians according to age bracket was different.

\section{Predictors that Influence Retirement Confidence and Job Commitment}

Linear regression was used to test if job rewards, job costs, job alternatives and job investments significantly predicted to have an effect on retirement confidence and job commitment. The results of the regression indicated that the predictor for retirement confidence explained $55.4 \%$ of the variance $\left(R^{2}=.55, F(4,13)=4.03, p<0.05\right)$. It was found that job investment $(p<.01)$ significantly predicted retirement confidence.

The results of the regression among overseas Filipino workers also indicated that the predictor for retirement confidence explained $99.8 \%$ of the variance $\left(R^{2}=.99, F(4,13)\right.$ $=1535, p<.001)$. It was found that job alternatives $(p<$ .001) significantly predicted retirement confidence. This is supported by the study of (United Arab Emirates, 2017), titled "The Power of Employee Benefits in a Fast Changing Workplace". Business employers in United Arab Emirates are ex periencing fast turnover of employees. In the study it was discussed that there was a mismatch of views with regards to the work environment. More than half of the employers perceived that the place is a great place to work while less number of employees perceived that the place is a great working environment. In 2017, only $39 \%$ did not consider a need to have a comparable increase in employee benefits for the employees to be attracted to say and work longer. Employees believed that there is a need to tailor the benefits offering of employers to their needs and expectations.

From the study of (Raziq, 2014), results revealed that working environment has a positive relationship with employee's job satisfaction. Job satisfaction will allow the employee voluntarily to stay and work longer or become loyal to engage with his work. However, job rewards, job costs, job alternatives and job investments were tested and reflected no significant effect on job commitment among Filipino workers in the domestic and overseas.

The result of the correlation of retirement confidence to the job commitment proves significant, $(r(18)=0.50, p<.05)$, this is supported by the good reputation of Filipino workers as good and dedicated workers in the overseas.In the view point of economic orientation, it is practical and acceptable for an employee to retire only if he is ready in almost all aspects (Quinn \& Burkhauser, 1990; Guillemard \& Rein, 1993; Herold et al., 2008; Wang \& Shultz, 2010). Also, in the overseas bridge employment is more applicable. Bridge employment refers to the opportunity where the employee is already receiving his pension but can still work. As for the study results on the relation of retirement confidence with the job commitment among Filipino workers in the domes- 
tic is supported by the study result of (Wang \& Shi, 2014). Also from the study of (Maurits, De Veer, Van Der Hoek, \& Francke, 2015), the study reveals that being committed to the job does not mean retirement confidence for it depends on the job satisfaction.

TABLE 4. Regression results for job rewards, job cost, job alternatives and job investment to retirement confidence

\begin{tabular}{|c|c|c|c|c|c|c|}
\hline \multicolumn{7}{|c|}{ Retirement Confidence } \\
\hline & \multicolumn{3}{|l|}{ Domestic } & \multicolumn{3}{|l|}{ Overseas } \\
\hline & $\begin{array}{l}\text { Estimated } \\
\text { Std. Error }\end{array}$ & $p$-value & Conclusion & $\begin{array}{l}\text { Estimated } \\
\text { Std. Error }\end{array}$ & $p$-value & Conclusion \\
\hline Constant & -43.414 & & -0.37946 & & & \\
\hline MeanJoRe & 7.456 & 0.25214 & Not Significant & -0.3191 & 0.729 & Not Significant \\
\hline MeanJocost & -0.16435 & 0.08535 & Not Significant & 0.1717 & 0.787 & Not Significant \\
\hline MeanjoAlt & 1.834 & 0.7815 & Not Significant & 0.98568 & $<2 \mathrm{e}-16^{* * *}$ & Significant \\
\hline Meanjoinv & 14.358 & $0.00435^{* *}$ & Significant & -0.0536 & 0.911 & Not Significant \\
\hline$R$-squared & 0.5538 & & 0.9979 & & & \\
\hline Adjusted $R$-squared & 0.4165 & & 0.9972 & & & \\
\hline No. of Observation & 18 & & 18 & & & \\
\hline
\end{tabular}

Note. $\dagger=p<.10,{ }^{*}=p<.05,{ }^{* *}=p<.01,{ }^{* * *}=p<.001$. Domestic $N=18$, Overseas $N=18$ for all analyses.

TABLE 5. Spearman Rho Correlation of Independent Variable and Dependent Variable

\begin{tabular}{|c|c|c|c|c|c|c|}
\hline \multicolumn{7}{|l|}{ Job Commitment } \\
\hline & \multicolumn{3}{|l|}{ Domestic } & \multicolumn{3}{|c|}{ Overseas } \\
\hline & Rho & $p$-value & Conclusion & Rho & $p$-value & Conclusion \\
\hline Retirement Confidence & -0.24724 & 0.3226 & Not & 0.502 & 0.03392 & Significant \\
\hline
\end{tabular}

\section{CONCLUSION AND RECOMMENDATION}

Results from this study showed that respondents' low confidence level falls between not too confident and somewhat confident. Respondents' allocation on their current income for retirement is in small percentage as compared to their current income from their answers to open ended questions. Filipinos who are working in the overseas temporarily work just to accumulate wealth for a living. Further study should be conducted on additional independent variables such as number of works years in current job, number of more years to work in the current job, factors of not staying in the current job, and factors of staying in the current job.

\section{THEORETICAL AND PRACTITIONER IMPLICATIONS}

The findings of this study could serve as a reflection tool for Overseas Filipino Workers' to utilize options on alternatives to gain retirement confidence about (a) the personal needs during retirement without sacrificing happiness and health, (b) financial back up while they are still capable of earning, (c) the capacity to cover medical expenses during retirement, (d) the ability to cover basic consumption expenditures, and (e) the ability to cover expenses throughout their life. With an advanced idea on the factors affecting ISSN: 2414-309X

DOI: $10.20474 /$ jabs-4.3.2 retirement confidence for all genders, employers can better satisfy their employees in formulating internal marketing programs that would best serve the internal customers (employees). Policymakers and educators could benefit from this research by considering the results in formulating internal marketing strategies such as rewards and benefits that would provide retirement confidence. Further, education materials can be developed in relation to retirement confidence specifically for each gender.

\section{LIMITATIONS}

Convenience Sampling was utilized to gather data from domestic and overseas Filipino workers from Dubai, Qatar, and Saudi Arabia and New York. Workers covered in the study were all working in the academe and various industries. Data gathered from 36 questionnaires were used to present the correlation between Demographic Factors and Retirement Confidence and identify the Predictors that influence retirement confidence and job commitment usinglinearregression. The current survey does not include psychological factors. Findings from this study could not be generalized to OFWs and domestic workers. 


\section{REFERENCES}

Ardyanfitri, . W. R., H. (2016). The influence of job career development opportunities, training, occupational safety and health on the job satisfaction of employees in the Telkom University. Journal of Administrative and Business Studies, 2(5), 231-240. doi:https://doi.org/10.20474/jabs-2.5.3

Britiller, M. C., Pesigan, J. A., Pillado, M., Portuguese, N., \& Principe, J. (2013). Life satisfaction of adults in retirement age. E-International Scientific Research Journal, 5(3), 2094-1749.

Caryl, E. (2011). The investment model of commitment processes. Handbook of Theories of Social Psychology, 4(6), 218-231. doi:https://doi.rg/10.4135/9781446249222.n37

Chipongian, L. (2017). Filipino savers are rising-BSP: Manila bulletin. Retrieved from https://goo.gl/qQKF31 (accessed on 15 August 2017)

De vera, B., \& Lucas, D. (2018). March inflation hits 4.3\%. Retrieved from https://goo.gl/cJCw5k (accessed on 23 April 2018)

Global Saving and Investment Report. (2014). Are we financially prepared for the future? Retrieved from https://goo.gl/ M7BDEg (accessed on 15 January 2016)

Goda, G. S., Manchester, C. F., \& Sojourner, A. (2013). Do income projections affect retirement saving? Center for Retirement Research at Boston College, 4(13), 20-45. doi:https://doi.org/10.3386/w17927

Green, P. I., Finkel, E. J., Fitzsimons, G. M., \& Gino, F. (2017). The energizing nature of work engagement: Toward a new need-based theory of work motivation. Research in Organizational Behavior, 1(4), 1-18. doi:https://doi.org/10.1016/ j.riob.2017.10.007

Guillemard, A. M., \& Rein, M. (1993). Comparative patterns of retirement: Recent trends in developed societies. Annual Review of Sociology, 19(1), 469-503. doi:https://doi.org/10.1146/annurev.soc.19.1.469

Hashim, D. B., Pin, F. B., \& Isa, M. Y. B. M. (2017). Factors influencing savings rate in Malaysia. International Journal of Economics and Finance, 9(6), 52-60. doi:https://doi.org/10.5539/ijef.v9n6p52

Herold, D. M., Fedor, D. B., Caldwell, S., \& Liu, Y. (2008). The effects of transformational and change leadership on employees' commitment to a change: A multilevel study. Journal of Applied Psychology, 93(2), 346-357. doi:https://doi.org/ 10.1037/0021-9010.93.2.346

Hoai, N. N., \& Thanwadee, H. (2015). Investigating factors influencing profits enhancement in real estate companies in Ho Chi Minh City, Viet Nam. International Journal of Business and Administrative Studies, 1(3), 107-113. doi:https://doi.org/ 10.20469/ijbas.10005-3

Lauren, F., \& Brandi, S. (n.d). The future of retirement in china: Perceptions and concerns. Retrieved from https://goo.gl/ 9Z563g (accessed on 23 April 2018)

Lee, A. A. C. J. M. T. V. J. W. K. . N. H., C. (2016). Employee job satisfaction and engagement: Revitalizing a changing workforce. Retrieved from https://goo.gl/dnMmjJ (accessed on 12 October 2015)

Madiawati, P. N., \& Pradana, M. (2016). The appeal of celebrity endorsers and halal certificates on customers' buying interest. Journal of Administrative and Business Studies, 1(1), 28-34. doi:https://doi.org/10.20474/jabs-1.1.5

Mandigma, M. B. S. (2016). Retirement preparedness of middle-income filipinos. World, 6(1), 45-67.

Mansor, M. F., Hong, C. C., Abu, N. H., \& Shaari, M. S. (2015). Demographic factors associated with retirement planning: A study of employees in malaysian health sectors. Asian Social Science, 11(13), 108-120. doi:https://doi.org/10.5539/ ass.v11n13p108

Maurits, E. E., De Veer, A. J., Van Der Hoek, L. S., \& Francke, A. L. (2015). Factors associated with the self-perceived ability of nursing staff to remain working until retirement: A questionnaire survey. BMC Health Services Research, 15(1), 356-367. doi:https://doi.org/10.1186/s12913-015-1006-x

Newman, D. A., Jeon, G., \& Hulin, C. L. (2013). Retirement attitudes: Considering etiology, measurement, attitude-behavior relationships, and attitudinal ambivalence. In M. Wang (Ed.), Oxford library of psychology. The Oxford handbook of retirement. New York, NY: Oxford University Press.

Optimistic, C. (2017). Philippine economy to expand 50 pct by 2022: Economic planning secretary. Retrieved from https:// goo.gl/uCzLPe (accessed on 23 January 2018)

Piyachat, B. (2017). The relationships among resources' commitment reverse logistics innovation reverse logistics performance and reverse logistics cost savings: Manufacturing vs service industry. Journal of Administrative and Business 
Studies, 3(3), 122-135. doi:https://doi.org/10.20474/jabs-3.3.2

Prudential Financial. (2017). Why employers should care about the cost of delayed retirements. Retrieved from https:// goo.gl/ofmYt5 (accessed on 3 March 2018)

Quinn, J. F., \& Burkhauser, R. V. (1990). Work and retirement. San Diego, CA: Academic Press.

Raziq, . M. R., A. (2014). Impact of working environment on job satisfaction. Procedia Economics and Finance, 23, 717-725. doi:https://doi.org/10.1016/S2212-5671(15)00524-9

Sabri, M. F., \& Juen, T. T. (2014). The influence of financial literacy, saving behaviour, and financial management on retirement confidence among women working in the malaysian public sector. Asian Social Science, 10(14), 40-50. doi:https:// doi.org/10.5539/ass.v10n14p40.

Selvina, M. (2016). Indonesian accountant vs foreign accountant in Indonesian job competition as an effect of Asean economic community 2015. International Journal of Business and Administrative Studies, 2(1), 16-19. doi:https://doi.org/ 10.20469/ijbas.2.10004-1

Semmer, N. K., Elfering, A., Baillod, J., Berset, M., \& Beehr, T. A. (2014). Push and pull motivations for quitting. Zeitschrift Fur Arbeits- Und Organisations Psychologie, 58(4), 173-185. doi:https://doi.org/10.1026/0932-4089/a000167

Shanmugam, A., Abidin, F. Z., \& Tolos, H. (2017). Issues in retirement confidence among working adults in malaysia : A conceptual paper. Organisations Psychologie, 8(6), 1-11. doi:https://doi.org/10.9790/5933-0806020111

Treuren, G. (2013). The relationship between perceived job alternatives , employee attitudes and leaving intention . the relationship between perceived job alternatives, employee attitudes and leaving intention. Annual Review of Psychology, 10(6), 1-18.

United Arab Emirates. (2017). The power of employee benefits in a fast changing workplace. Retrieved from https:// goo.gl/kr1ccN (accessed on 3 January 2018)

Wang, M., \& Shi, J. (2014). Psychological research on retirement. Annual Review of Psychology, 65(1), 209-233. doi:https:// doi.org/10.1146/annurev-psych-010213-115131

Wang, M., \& Shultz, K. S. (2010). Employee retirement: A review and recommendations for future investigation. Journal of Management, 36(1), 172-206. doi:https://doi.org/10.1177/0149206309347957

Yaemjamuang, B. (2017). Investigating motivation of the hotel employees at the operational level: A case study of the hotel business in Samut Songkram Province, Thailand. International Journal of Business and Economic Affairs, 2(1), 8-11. doi:https://doi.org/10.24088/ijbea-2017-21002 